\title{
RESIKO DAN HAZARD PERAWAT DALAM MEMBERIKAN ASUHAN KEPERAWATAN DI RUMAH SAKIT
}

\author{
Khairun Nisa \\ Email : K.khairunnisa1311@gmail.com
}

\begin{abstract}
ABSTRAK
Kesehatan Kerja (K3) adalah suatu upaya dalam menciptakan perlindungan dan keamanan dari macam-macam risiko berbahaya. Perawat merupakan profesi yang memiliki peran yang begitu besar terhapat pasien di Rumah sakit. Ada banyak hal yang biasa di lakukan perawat di rumah sakit mulai dari memberikan asuhan kepada pasin, memberikan pendidikan kesehatan, serta merawat pasien. Dalam melakukan asuhan keperawatan sering terjadi bahaya atau kecelakaan yang terjadi selama dalam proses kerja. Bahaya yang terjadi bisa berupa ahaya fisik, biologi dan lain-lain. ada banyak faktor yang bisa membahayakan perawat. Faktor-faktor tersebut antara lain yaitu: Faktor bahaya kimia, seperti: gas, Debu, bahan beracun, dan lain-lain. Faktor bahaya biomekanik, seperti: posisi kerja gerakan, dan lain-lain titik Faktor bahaya sosial psikologis, seperti: stres, kekerasan dan lain-lain. risiko hazard saat melakukan pengkajian bisa berupa salah dalam pendukumentasian, salah dalam memberikan asuhan yang bisa menimbulkan bahaya.
\end{abstract}

Kata kunci : Hazard, perawat. Hazard dalam asuhan keperawatan.

\begin{abstract}
Occupational Health (K3) is an effort to create protection and security from various dangerous risks. Nurse is a profession that has a big role for patients in the hospital. There are many things that nurses usually do in the hospital, starting from providing care to patients, providing health education, and caring for patients. In conducting nursing care, there are often hazards or accidents that occur during the work process. The hazards that occur can be physical, biological and other hazards. there are many factors that can harm a nurse. These factors include: Chemical hazard factors, such as: gas, dust, toxic materials, and others. Biomechanical hazard factors, such as: work position, movement, etc. Social-psychological hazard factors, such as stress, violence and others. the risk of hazard when carrying out the assessment can be in the form of incorrect documentation, wrongly providing care that can cause danger.
\end{abstract}

Key words: Hazard, nurse. Hazard in nursing care. 


\section{LATAR BELAKANG}

Seiring dengan berjalannya waktu, ada banyak hal yang mungkin terjadi. Dengan berkembangnya teknolologi dan meningkatnya jumlah pekerja, banyak dampak positif maupun negatif yang mulai muncul di lapangan kerja. Dilihat dari banyaknya kejadian/kecelakaan yang di sebabkan oleh pekerjaan membuat Keselamatan pekerja menjadi hal yang perlu diperhatikan. Berdasarkan UndangUndang No 13 tahun 2003 membahas tentang ketenagakerjaan dalam Pasal 86 disebutkan bahwa setiap pekerja/buruh memiliki hak untuk mendapatkan perlindungan atas keselamatan dan kesehatan kerja. Pernyataan ini ditegaskan kembali dalam Undang-Undang No. 36 tahun 2009 tentang kesehatan yang menyatakan bahwa pengelola tempat kerja memiliki kewajiban melakukan segala bentuk upaya kesehatan melalui peningkatan, pencegahan, pengobatan serta pemulihan bagi tenaga kerja.

Pada dasarnya Keselamatan dan Kesehatan Kerja (K3) adalah suatu upaya dalam menciptakan perlindungan dan keamanan dari macam-macam risiko berbahaya. baik secara fisik, mental maupun emosional terhadap pekerja, perusahaan, masyarakat dan lingkungan, kemudian keselamatan dan kesehatan kerja diharapkan mampu menciptakan kenyamanan kerja dan keselamatan kerja yang tinggi. Pada era globalisasi dan pasar bebas WTO dan GATT menyatakan bahwa keselamatan dan kesehatan kerja rumah sakit merupakan suatu prasyarat yang ditetapkan dalam hubungan ekonomi perdagangan barang dan jasa antar negara yang harus dipenuhi oleh seluruh negara anggota, termasuk Indonesia. Dalam rangka mengantisipasi serta mewujudkan perlindungan masyarakat pekerja Indonesia.

Sistem manajemen keselamatan dan kesehatan kerja merupakan satu dari beberapa bagian sistem manajemen perusahaan secara keseluruhan yang meliputi struktur organisasi, perencanaan, pelaksanaan, tanggung jawab, prosedur, proses, dan sumber daya yang digunakan dalam pengembangan, penerapan, pencapaian, pengkajian, dan pemeliharaan kebijakan keselamatan dan kesehatan kerja dalam hal pengendalian resiko yang berkaitan dengan kegiatan kerja guna terciptanya tempat kerja yang aman, efisien,dan produktif (penjelasan Undang Undang No 13 Tahun 2013 pasal 87, ayat 1). Selain berpatokan pada UU tersebut, 
Sistem Manajemen Keselamatan dan Kesehatan Kerja pun harus mengarah pada PP No.50 Tahun 2012.Keselamatan dan kesehatan kerja bagi para pekerja di Rumah Sakit dan fasilitas medis lain tidak kalah pentingnya dibandingkan dengan sektor industri lainnya. Disadari atau tidak, di lingkungan RS ada banyak sediaan bahan, alat dan proses kerja yang berpotensi membahayakan. Angka Kecelakaan Akibat Kerja (KAK) di RS juga cukup tinggi. Salah satu tempat yang memiliki potensi berbahaya adalah rumah sakit. Banyak perawat yang terpapar bahaya akiat Pada dasarnya pekerjaannya. permasalahan tersebut timbul akibat lemahnya pihak manajemen dalam menjalankan K3 RS dengan baik dan benar, dan tingkat kesadaran pekerja RS akan K3 yang masih kurang. Di samping itu berbagai masalah K3 kurang mendapat perhatian sebagaimana mestinya.

Sebagai perawat ada banyak bahaya (hazard) yang bisa di alamiselama berada di rumah sakit. Hazard merupakan perubahan atau tindakan yang berpotensi meningkatkan risiko insiden pada pasien yang dapat berpotensi menimbulkan bencana tetapi tidak semua bahaya selalu menjadi bencana. Identifikasi Bahaya (Hazards Identification), Penilaian Risiko (Risk Assessment) serta Pengendalian Risiko (Risk Control) yang di singkat dengan HIRARC adalah suatu elemen pokok dalam sistem manajemen Keselamatan dan Kesehatan Kerja yang berhubungan dengan upaya pencegahan dan pengendalian bahaya. Keseluruhan proses dari HIRARC yang disebut juga dengan manajemen risiko (risk management), yang selanjutnya akan menghasilkan dokumen HIRARC yang sangat berguna untuk mencegah terjadinya kecelakaan kerja.

Ada 5 faktor yang bisa menyebabkan para pekerja mendapatkan bahaya(hazard) ketika sedang bekerja. 5 faktor tersebut terdiri dari:
(1) faktor kimia
(2) faktor fisika
(3) faktor biologi
(4) faktor lingkungan kerja
(5) faktor psikologi 


\section{METODE PENELITIAN}

Penelitian ini merupakan penelitian kualitatif dengan menggunakan jurnal sebagai bahan penelitian. Jurnal-jurnal yang di gunakan merupakan jurnal terpercaya dan memuat informasi terkait judul yang sedang di teliti. Pengumpulan informasi di sini bertujuan untuk mencari dan mendalami informasi terkait Resiko dan Hazard Perawat Dalam Memberikan Asuhan Keperawatan di Rumah Sakit. Hasil dari penelitian ini akan disatukan dan di abadikan dalam bentuk jurnal kembali.

\section{HASIL}

Ada banyak hal yang perlu di perhatikan dalam menjalankan aktivitas sebagai seorang perawat. Pengetahuan terkait kesehatan dan keselamatan kerja harus selalu digali dan diterapkan dalam kehidupan sehari-hari. Pelatihan bagi perawat merupakan salah satu hal yang penting untuk meningkatkan perilaku perawat dalam menjaga keselamatan diri. Ada banyak bahaya yang bisa menimpa perawat dalam memberikan asuhan keperawatan di Rumah Sakit. Bahaya di rumah sakit akan berdampak pada kesehatan, keselamatan perawat yang juga akan mempengaruhi kualitas pelayanan di rumah sakit. Hal ini perlu mendapat perhatian baik dari perawat maupun rumah sakit. Jika keselamatan dan kesehatan perawat tidak diperhatikan maka akan terjadi peningkatan absensi, ketidakpuasan bekerja, produktifitas menurun, hilangnya kepercayaan diri, kreatifitas dan konsentrasi perawat dalam bekerja juga menurun.

Keselamatan dan kesehatan kerja bertujuan melindungi pekerja agar mampu meningkatkan produktifitas nasiona serta Menjamin pekerja yang berada ditempat kerja serta merawat sumber produksi secara aman dan efisien. Untuk menghindari bahaya dalam memberikan asuhan keperawatan di rumah sakit, perawat harus mampu melihat keadaan, dan berfikir secara kritis. Agat terhindar dari penyakit infeksi maka perawat harus menerapkan protokol kesehatan dan menggunakan APD dan mencuci tangan sebelum dan sesudah melakukan tindakan keperawatan. 


\section{PEMBAHASAN}

Rumah sakit merupakan suatu instansi pelayanan kesehatan yang padat modal, padat teknologi, dan padat sumber daya manusia dan dalam prosesnya banyak mengandung potensi bahaya seperti, bahaya radiasi, bahan kimia toksik, temperature ekstrim, ergonomik, dan seb againya, komponen-komponen berbahaya diatas dapat menimpa keselamatan dan kesehatan pekerja. Karena pekerja merupakan salah satu unsur yang penting dalam pengendalian faktor produksi dan penentuan keberhasilan suatu perusahaan, maka diperlukan adanya kemampuan dan ketrampilan kerja serta jaminan perlindungan dan memberikan ketenangan serta keamanan kerja. Dalam Undang Undang No. 13 Tahun 2003 menegaskan dalam pasal 86, berbunyi bahwa setiap pekerja / buruh mempunyai hak dalam memperoleh perlindungan atas keselamatan dan kesehatan kerja

Perawat merupakan profesi yang memiliki peran yang begitu besar terhapat pasien di Rumah sakit, perawat memiliki tanggung jawab dan kewajiban yang besar dalam menjalankan tugasnya. Ada banyak hal yang biasa di lakukan perawat di rumah sakit mulai dari memberikan asuhan kepada pasin, memberikan pendidikan kesehatan, serta merawat pasien. Sebagai seorang perawat yang memiliki banyak peran, dan banyak menghabiskan waktu di rumah sakit tidak heran apabila sering terjadi bahaya atau kecelakaan yang terjadi selama dalam proses kerja. Bahaya yang terjadi bisa berupa ahaya fisik, biologi dan lainlain. ada banyak faktor yang bisa membahayakan perawat. Faktor-faktor tersebut antara lain yaitu:

1. Faktor bahaya kimia, seperti: gas, Debu, bahan beracun, dan lain-lain.

2. Faktor bahaya biomekanik, seperti: posisi kerja gerakan, dan lain-lain titik

Faktor bahaya sosial psikologis, seperti: stres, kekerasan dan lain-lain.

\section{klasifikasi hazard diklasifikasikan sebagai biologis dan non biologis.}

\section{Bahaya biologis}

Didefinisikan untuk dimasukkan luka laserasi, luka yang tajam, kontak langsung dengan spesimen yang terkontaminasi bahan biohazardous, bioterorisme, yang ditularkan melalui darah patogen, penyakit 
infeksi, penyakit udara, penyakit vektor yang ditanggung, dan kontaminasi silang dari material kotor.

\section{Bahaya nonbiologis}

Didefinisikan untuk termasuk fisik, psikososial, dan ergonomis bahaya: bahaya fisik termasuk slip, perjalanan, jatuh, luka bakar, fraktur, radiasi dari sinar-x, kebisingan, dan radiasi nonionisasi.

Kesehatan merupakan keadaan sehat baik secara fisik, mental, spiritual maupun sosial yang memungkinkan setiap orang untuk hidup produktif secara sosial dan ekonomis. Tingkat kesehatan yang optimal merupakan derajat kesehatan setinggi -tingginya sesuai dengan lingkungan yang perlu dicapai agar asyarakat dapat bekerja lebih produktif dan hidup sesuai dengan martabat, kesehatan sendiri, kesehatan keluarga dan kesehatan lingkungan. terjadinya kecelakaan di RS $41 \%$ lebih besar dari pekerja di industri lain. Kasus yang sering terjadi adalah tertusuk jarum, terkilir, sakit pinggang, tergores/terpotong, luka bakar, dan penyakit infeksi dan lain-lain.

Upaya yang dapat di lakukan dalam mencapai kesehatan perlu memperhatikan faktor risiko terkait masalah kesehatan yang terjadi. Menurut National Institute for Occupational Health and Safety (NIOHS, 2006) menyatakan bahwa penyakit dan kecelakaan kerja yang dialami oleh pekerja diakibatkan oleh lima faktor. Kelima faktor tersebut adalah:

(1) faktor kimia, contohnya cairan, gas, partikel, debu, uap dan serbuk kimia.

(2) faktor fisika antara lain gelombang elektromagnetik, radiasi ion, kebisingan, getaran, panas, dan dingin.

(3) faktor biologi, seperti serangga, bakteri patogen, jamur.

(4) faktor lingkungan kerja, seperti gerakan monoton, kelelahan, ketegangan otot/boredom.

(5) faktor psikologi yaitu, stress, hubungan yang kurang harmonis antar pekerja atau hubungan yang kurang harmonis antara staf dengan atasan.

Dalam memberikan asuhan keperawatan ada banyak resiko bahaya yang bisa terjadi akibat fisik, psikososial, dan ergonomis bahaya: bahaya fisik termasuk slip, perjalanan, jatuh, luka bakar, fraktur, radiasi dari sinar-x, kebisingan, dan radiasi nonionisasi. Bahaya psikososial tyang termasuk fisik, penyalahgunaan psikososial, seksual, dan verbal dan menekankan. Bahaya ergonomis Adalah gangguan muskulusskeletal cedera seperti nyeri otot, strain atau terkilir. Identifikasi Hazard Mengidentifikasi suatu bahaya 
adalah upaya sistematis untuk mengetahui potensi bahaya yang ada di lingkungan kerja.

Perawat sangat berpotensi mengalami kecelakaan daalam menjalankan tugasnya di rumah sakit. perawat di rumah sakit memiliki potensi kecelakaan yang besar. Kecelakann tersebut bisa akibat kelalaian sendiri maupun kecelakaan murni. Ada beberapa kasus hazard yang di dapatkan perawat dalam dalam memberikan asuhan keperawatan di rumah sakit antara lain, yaitu:

\section{1. risiko hazard saat melakukan} pengkajian. saat perawat melakukan pengkajian terhadap pasien yang memiliki riwayat penyakit infeksi, terinfeksi tersebut bisa di akibatkan karena pasien yang tidak jujur, dan bisa juga karena perawat tidak menggunakan alat pelindung diri saat melakukan pengkajian

\section{Risiko dan Hazard dalam pelaksanaan} asuhan keperawatan, jika perawat salah dalam melakukan mengkaji terhadap asien, maka Perawat akan salah dalam asuhan keperawatan atau pengobatan yang bisa berpotensi terhadap keselamatan pasien. Jika asuhan yang diberikan salah maka ada banyak efek yang bisa terjadi, misalnya perawat salah dalam memberikan obat,maka pasien bisa terkena imbasnya.

\section{Risiko Hazard dalam mengevaluasi} asuhan keperawatan, Kesalahan pada saat melakukan evaluasi dalam pelaksanaan asuhan keperawatan dapat mengakibatkan pendokumentasian yang salah.

Ketika pasien terlihat dalam keadaan tidak terkontrol dan susah untuk didekati, maka perawat dapat melakukan pengkajian kepada keluarganya terlebih dahulu, Saat melakukan pemeriksaan fisik, perawat harus meminta persetujuan dari klien terlebih dahulu, Perawat harus menggunakan APD saat melakukan pemeriksaan fisik pada klien, Perawat juga harus melaporkan setiap adanya tindakan kekerasan dalam bentuk apapun kepada pihak rumah sakit, Perawat juga tidak memegang benda yang mungkin telah terkontaminasi, Sebelum menuju klien hendaknya perawat mencuci tangan. Upaya mencegah dan meminimalkan risiko dan hazard dalam tahap perencanaan asuhan keperawatan yaitu Identifikasikan sumber bahaya yang mungkin dapat terjadi saat menyusun rencana keperawatan, Lakukan penilaian faktor risiko dengan jalan melakukan penilaian bahaya potensial yang menimbulkan risiko kesehatan dan keselamatan kerja saat menyusun perencanaan 
Upaya mencegah dan meminimalkan risiko dan hazard pada tahap implementasi asuhan keperawatan yaitu Perawat harus menjaga diri dari infeksi dengan mempertahankan teknik aseptik seperti mencuci tangan, memakai APD lengkap, menggunakan alat kesehatan dalam keadaan steril, Perawat harus mematuhi SOP yang telah ditetapkan oleh rumah sakit dan tidak terburu-buru dalam melakukan tindakan Perawat hendak memperhatikan cara menutup jarum suntik yang benar susunan sel hidung kamu banyak diharapkan perawat dapat menghindari kontak langsung dengan segala macam cairan klien, apabila dirasa sistem imunitas tubuh sedang menurun atau tidak menggunakan APD Perawat sebaiknya menerapkan perilaku hidup bersih dan juga sehat serta menerapkan pola hidup yang sehat pula, Perawat harus menanamkan sifat kehati-hatian, konsentrasi yang tinggi, dan ketenangan saat bekerja terutama saat melakukan tindakan yang beresiko kepada pasien, Perawat dituntut untuk belajar mengoperasikan alat-alat yang sudah disediakan oleh pihak rumah sakit dengan tujuan mengurangi risiko cedera baik bagi klien maupun bagi perawat sendiri.Upaya mencegah dan meminimalkan risiko dan hazard pada evaluasi asuhan keperawatan dilakukan untuk menilai sejauh mana intervensi dan implementasi yang diberikan berhasil dalam perkembangan kesembuhan pasien ada beberapa cara untuk mencegah dan mengurangi resiko hazard. Cara yang dapat dilakukan untuk mencegah risiko dan hazard dalam evaluasi asuhan keperawatan yaitu Identifikasi sumber bahaya yang mungkin terjadi saat menyusun evaluasi keperawatan, dapat dilakukan dengan mempertimbangkan kondisi dan kejadian yang dapat menimbulkan potensi bahaya baik pada klien maupun kepada diri perawat sendiri

Beberapa hal yang bisa di lakukan dalam mengendalikan Pengendalian Risiko bahaya antara lain yaitu:

\section{Upaya pengendalian bahaya fisika (pencahayaan)}

Dalam melakukan tindakan keperawatan perawat harus memperhatikan kebutuhan dan resiko penerangan cahaya yang ada di sekitar pasien. Kemudian, menggunakan bahan kimia seperti desinfektan untuk menghindari infeksi. Petawat juga perlu memperhatikan keamaanan bahan-bahan kimia yang ada di sekitar pasien, perawat tidak boleh lalai dalam menggunakan dan menempatkan bahan kimia karena berpotensi berbahaya juga untuk pasien terebut

\section{Upaya yang bisa di lakukan untuk} menghindari bahaya biologi (tertular penyakit AIDS, Hepatitis A, Hepatitis B, 
Tuberkulosis) yaitu dengan selalu menerapkan protokol kesehatan, dan menggunakan APD. yang dibutuhkan sesuai dengan pekerjaan, seperti menggunakan sarung tangan dan masker ketika kontak langsung dengan pasien.

Komunikasi dan hubungan tim juga merupakan suatu hal penting dalam meningkatkan keselamatan perawat dalam memberikan asuhan keperawatan. Komunikasi dan hubungan tim merupakan

\section{PENUTUP}

Strategi yang dapat dilakukan untuk menghindari terjadinya hazard dalam memberikan asuhan keperawatan di rumah sakit yaitudengan mengikuti pelatihanpelatihan yang bisa meningkatkan pengetahuan dan keterampilan perawat terkait keselamatan di rumah sakit. Cara yang dapat dilakukan untuk mencegah risiko dan hazard dalam evaluasi asuhan keperawatan yaitu Identifikasi sumber bahaya yang mungkin terjadi saat menyusun evaluasi keperawatan, dapat dilakukan dengan mempertimbangkan kondisi dan kejadian yang dapat menimbulkan potensi bahaya baik pada sebuah proses yang bisa dilaksanakan melalui rapat untuk memperoleh informasi, dan pendapat dalam melaksanakan program kerja, evaluasi program kerja, penyelesaian masalah bersama, bimbingan arahan, serta upaya yang bisa di lakukan untuk mengurangi kesenjangan komunikasi antar pimpinan dan sesama staf.

klien maupun kepada diri perawat sendiri. ningkatkan perilaku dalam menjaga keselamat-an diri dari bahaya fisik biologis, kimia, ergonomik, psikososial, dan lukaluka benda tajam. Untuk menghindari bahaya infeksi di rumah sakit, perawat bisa menerapkan teknik sterilisasi, menggunakan alat pelindung diri seperti masker, sarung tangan, dan lain lain. dalam upaya mencegah terjadinya kecelakaan di rumah sakit Perawat harus selalu berhatihati, selalu konsentrasi, tidak boleh panik dan ketenangan dalam menangani permasalahan dan saat Perawat dituntut untuk belajar mengoperasikan alat-alat 
yang sudah disediakan oleh pihak rumah sakit dengan tujuan mengurangi risiko cedera baik bagi klien maupun bagi perawat sendiri. Usaha yang dilakukan dalam mengurangi risiko dan hazard pada evaluasi asuhan keperawatan dilakukan untuk menilai sejauh mana intervensi dan implementasi yang diberikan berhasil

\section{REFERENSI}

Afandi, A. D.,Arie. Yuniar. (2014).Usulan Penanganan Identifikasi Bahaya Menggunakan Teknik Hazard Identification Risk Assessment and Determining Control (HIRADC) (Studi Kasus di PT. Komatsu Undercarriage Indonesia).Jurnal Online Institut Teknologi Nasional. $3(2): 35-25$.

Indragiri,S. Y.,Triesda. (2017). Manajemen Risiko K3 Menggunakan Hazard Identification Risk Assessment And Risk Control (HIRARC).jurnal Program Studi S1 Kesehatan Masyarakat STIKes Cirebon. 10801094.

M.,Iwan. Rahman, Abd. (2017).Analisis Risiko Kesehatan dan Keselamatan dalam perkembangan kesembuhan pasien ada beberapa cara untuk mencegah dan mengurangi resiko hazard.

Kerja

pada

Perawat.JKP.5(3):229-241.

Putri, Oktaviana Zahratul.,dkk.2017. Analisis Risiko Keselamatan Dan Kesehatan Kerja Pada Petugas Kesehatan Instalasi Gawat Darurat Rumah Sakit Akademik Ugm. Jurnal Kesehatan Vol 10 (1)

Prasetyo, Erwan Henri.,dkk.2018. Analisis Hira (Hazard Identification And Risk Assessment) Pada Instansi X Di Semarang.Jurnal Kesehatan Masyarakat Vol 6 (5)

Ramdan, Iwan, M.,dkk.2017. Analisi Risiko Kesehatan Dan Keselamatan 
Kerja (K3) Pada Perawat.Jurnal Kesehatan Vol 5 (3)

Supriyadi., dkk.2017.Identifikasi Bahaya dan Penilaian Risiko pada Divisi Boiler Menggunakan Metode Hazard Identification Risk Assesment and Risk Control (HIRARC).Journal of Industrial Hygiene and Occupational Health Vol 1(2)

Simamora, R. H. (2011). ROLE CONFLICT OF NURSE RELATIONSHIP WITH PERFORMANCE IN THE EMERGENCY UNIT OF HOSPITALS RSD DR. SOEBANDI JEMBER. The Malaysian Journal of Nursing, 3(2), 2332.

Tarigan, H., Salim, U., Troena, E.A., \& Setiawan, M. (2012). Pengetahuan Individu Dan Pengembangan Kerja Tim Berpengaruh Terhadap Kinerja Perusahaan Di Kawasan Industri Mm 2100 Cikarang, Bekasi. Jurnal manajemen kewirausahaan. Diperoleh dari http://jurnalmanajemen.petra.ac.id/i ndex.php /man/article/view/18370

Tarwaka. Keselamatan dan kesehatan kerja manajemen dan implementasi k3 di tempat kerja. Surakarta: harapan press; 2014. 34. 13. 14. 267.

Wulan,Fatwa Hisadayah. 2019."Analisis Faktor Risiko dan Hazard dalam
Implementasi Keperawatan”. Skripsi.Fakultas Ilmi

Kesehatan.Keperawatan S1. UMP. 


